\title{
Enlightenment of Global Advancement for Future: One Belt One Road
}

\author{
Mukut Sikder $^{1}$, Xuecheng Dou ${ }^{1} \&$ Lita Davi $^{2}$ \\ ${ }^{1}$ College of Finance and Economics, Gansu Agricultural University, Lanzhou, Gansu, P.R. China \\ ${ }^{2}$ Department of Business administration, Premier University, Chittagong, Bangladesh \\ Correspondence: Xuecheng Dou, Gansu Agricultural University, College of Finance and economics, Anning \\ District, 730070, Lanzhou, Gansu Province, China. Tel: 86-138-9310-1197. E-mail: tigerzyx @163.com
}

Received: March 31, 2020

Accepted: April 29, 2020

Online Published: May 28, 2020

doi:10.5539/ijef.v12n6p80

URL: https://doi.org/10.5539/ijef.v12n6p80

\begin{abstract}
The Belt and Road project is a traditional activity that assembles countries of the globe and simplifies several chances to achieve single tranquillity. The research purpose drives to analyzing conjugation of strategy improvement globally in posterior. It also analyzes because of the greatest, plan, prospects, and challenges of initiatives in the principle of international trade, diplomatic, neighbourly, and situational perspectives. This article usage characteristic access and secondary data, especially journal papers, annual reports, different data of administrative, e-books, Presentation document, and many web pages, which broadly focus are to visualize intentions. This research elaborates on associate nations and delicacy that aims to develop and diplomatic advantages derived from these activities. It enhances transportation through road pathway, air, and sea, cooperating discretion of economical involvement through a rood border trade, creativity, and regional development. This study also purposes hazards and objection attached to the project implementation. It shows the potential collaboration between associates of the program which is essential to meet One Belt One Road care of effective policy, system and regulations, exact strategy implementation, earnest judgment on administrative and trading multiplier.
\end{abstract}

Keywords: opportunities, global development, diplomatic advantages, collaboration, and implementation

\section{Introduction}

China takes countless incentive designs for full-grown work, and hard works are involved in package track-ways exclusively between China and countries. In 2013 Chinese leader Xi Jinping visited some countries officially, initiation a global development master plan which name mentioned Belt and Road Initiative. Outstandingly, China's role in the flow of global foreign agreements has been effectively revealed. There are two main parts to creativity, the land-raised "Silk Road Employment and Industry Tie" and the Sea Maritime Silk Road. In contrast, the Maritime Silk policy is stuck on the way to the ocean between the auxiliary regions, and this huge set contains two-thirds and three-quarters of the strong suite resources of the country-states worldwide (Peter, 2016). This recent policy will single frame simultaneously 65 countries and 4.4 billion communities (Du, 2016). It is the major economic stage of the world that will develop global expanding economic growth through renewable contributions (Chen, 2014).

Although China has estimated it as advocacy in opposition initiative's peaceable exit, the convenience of initiative is reachable for all persons living in the global for a policy as reciprocal collaboration, cantering, and emancipation (Sarker, Hossin, Yin, \& Sarkar, 2018). The principal intention of this paper is an explanation of the enquiry:

1) What is the key point of view about belt and road strategy?

2) Is traversable for the arrival of wide growth?

3) What kind of policy, possibilities and encounters are there in this initiative? And

We distillate the work for internal international success with a few recommendations in the same way about the origins, policies, possibilities, challenges and the relationship between the belt and the road initiative. This work describes China with a global presence. 


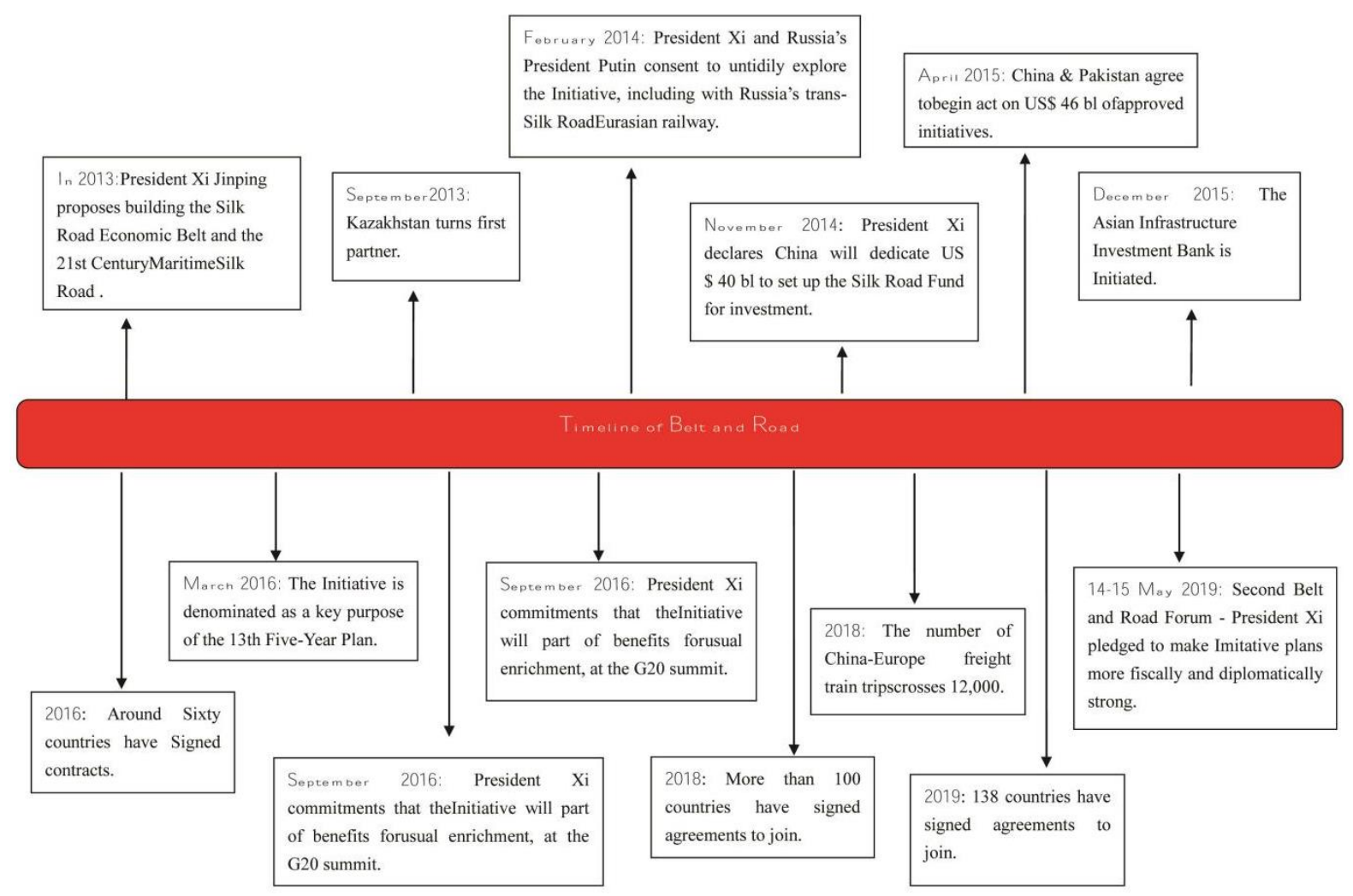

Figure 1. Timeline of Belt and Road initiative

\section{Methodology}

This article is comprising is of secondary information commonly collected from several Journal articles, reports, well-known database website, and usually deliberated the data from the year 2010 to almost present.

The research is positive in behaviour founded on a few exhibitors of global trade improvement forward to a comprehensive review of literature work. The updated data has been covered for the best recommendation for the synthesis of the Belt and Road initiative. It delivers the benefit to adjust and consider the former study, and this way giving invulnerable mounting for the progress of consciousness.

Data has been analyze from various aspects of global economy, Objections and prospects for conjugation, financial resources, engagement of good relationship nations, policy for accomplishment, compatibility of economic corridors, and ongoing international economic improvement.

\section{Review of Literature}

It enlarges a chance by improving a traditional infrastructural forward movement. It assembles the world community with administrative, International Trade and cultural explores (Uberoi, 2016). One Belt One Road is the reappear of the ancient Silk Road that influences the international trade by the whole of a massive segment of the globe beneath a roof. The Chinese governance has the biggest impact on the project as a cause of a promoter and the greatest economy (Mishra, 2016). Although few researchers consider that initiative is exclusively flourished on the accomplishment of the Chinese "Ride West" strategy but until it has an extraordinary result on the whole economy (Huang, 2016).

There still exists a various geographic region in China like Xinjiang as Central place of the One Belt and Fujian as the "main ground" for the "One belt one Road" for completing two large projects under Belt and Road initiative (Karl \& Chen, 2014). The areas few largest cities of China links through financial zone pass Southeast Asia, South Asia, Middle East, and Africa (Djankov \& Sean, 2016). Moreover, it covered the modern Silk Road initiative for joining the globe modernly which has been controlled by the Chinese Government. Other areas such as northern China, and Shaanxi province also significant to append China to central Asia by business trade (Li, Xiao, Wei, Lei, You, \& Rui, 2017). 


\subsection{Trade Enhancement and Opportunities}

This international economic enlargement approach concentrates comprehensively on the effect of positive impacts on power efficiency alongside it may help for China includes several regions. The primary aim of China, enormous investment and business collaboration which raises tariff contributions, enlarge international business and increases boost through new services alongside cross-border e-commerce development (Boamah, Appiah-Kubi, \& Osei, 2018). Few of argument that China's larger engagement in Asia and Africa has created a modern trade strategy in the countries (Sevilla Jr, 2017). Sino-Middle east friendships are creating a policy of a business improvement that bilateral relations, As usual, the priority government and civil community, and can build solidarity with all administrations (Qian, 2016).

A crucial point into critic in the United States, Western World, and East Asian country Japan, because of they are excessive capability, generally entrance to state-sanctioned financing organization with all-region cooperation, Chinese stakeholder can attitude not similarly of such as Western non-governmental organizations (Chaisse \& Matsushita, 2018). Another vital segment of global impact might have a chance to reduce business cost and sustainable engagement between the states involved in universal business, and initiative cooperate through $12 \%$ world trade (Konings, 2018). While business costs half-done among areas engaged in Enterprise, there are establish improvements in trade 35\% to 45\% between South Asian, Central Asia, and Europe accept Russia. The initiative will probably improve world GDP by $\$ 7$ trillion a year by 2040 and at the similar time progress global GDP by $4.2 \%$. It is believable to cooperate GDP in Asia 5\%, Whole Europe 11\% (Research, 2019).

Since the maximum of the initiative shareholder are economically improving nations so infrastructure expansion can be the chief precedence for international ongoing improvement under One belt one road initiative (Kevin \& Craig N, 2013). Many researchers described that strategy is the propagation, attainment, and composition a few Chinese policies for raising the supine Chinese economy by observing typical safety, trade and international affinity (Jinghan, 2017). Beside most major residences should be caught to steal the overpowering of business and investment, decreasing finance value and inspiring economic development (Duan, Ji, Liu, \& Fan, 2018). Economical value is most crucial aims of initiative which can be obtained by inspiring financial strategy cooperation for trade and investment, making cantonal economical organization, restorative coordination for hazard administration, and proving zonal appointments for governing economical risks (Kaplan, 2017).

Table 1 shows the summarized study review related to the work mentioned, and hope perfect accomplishment of policy might collaborate to write the economy from China to worldwide.

Table 1. Currently studies and reviews about Belt and Road initiative

\begin{tabular}{|c|c|c|}
\hline Primary issues & Journal/Source & Authors \\
\hline $\begin{array}{l}\text { The Influence of original plainness on work business: Belt } \\
\text { and Road Initiative in China. }\end{array}$ & $\begin{array}{l}\text { American Journal of Industrial and Business } \\
\text { Management }\end{array}$ & (Yu \& Sun, 2019) \\
\hline $\begin{array}{l}\text { Logistics and Economic outgrowth on the Silk Road } \\
\text { Economic Belt. }\end{array}$ & Technology and Investment & (Fang, 2016) \\
\hline The strategy of Taiwan's Perspective on China's Initiative. & Journal of Contemporary East Asia Studies & (Fang, 2016) (Hsueh, 2016) \\
\hline Between China and Pakistan Economic Corridor & ARCADA & (Aqeel, 2016) \\
\hline $\begin{array}{l}\text { Analysis of the Agricultural business between China and } \\
\text { nations of the Road and Belt policy. }\end{array}$ & Modern Economy & (Wang, Li, \& Hu, 2018) \\
\hline A view of Essay: The Silk Road in global story & Asian Review of World Histories & (Alfred J., 2014) \\
\hline China Geopolitics Maritime Silk Road Initiative. & Geopolitics & (F. Blanchard \& Flint, 2017) \\
\hline $\begin{array}{l}\text { Shanghai operator Free business area: New concepts of the } \\
\text { improve in the vision of Globalization. }\end{array}$ & Open Journal of Social Sciences & (Liang, 2015) \\
\hline $\begin{array}{l}\text { Chinese History on "One Belt, One Road" (一带一路) in } \\
\text { Geopolitical and dictatorial process. }\end{array}$ & The Professional Geographer & (Sidaway \& Yuan, 2017) \\
\hline Opportunities with Belt and Road & Center for Financial Stability & (Chua A. C., July 6, 2017) \\
\hline $\begin{array}{l}\text { China's Low-Carbon Economy improvement and Carbon } \\
\text { trade Mart observation Mechanism. }\end{array}$ & Low Carbon Economy & (Yang, 2017 ) \\
\hline $\begin{array}{l}\text { Competitiveness and Complementarity: An Empiric study } \\
\text { on Agricultural business between China and under the Belt } \\
\text { and road others nations. }\end{array}$ & Modern Economy & $\begin{array}{l}\text { (He, Zequn, \& Ningning, } \\
\text { 2016) }\end{array}$ \\
\hline $\begin{array}{l}\text { International system under president Xi Jinping: Westwards } \\
\text { ho-the China dream and one belt one road. }\end{array}$ & International Affairs & (Ferdinand, 2016) \\
\hline
\end{tabular}




\begin{tabular}{|c|c|c|}
\hline $\begin{array}{l}\text { Advantages and Challenges for EU Small and Medium } \\
\text { Enterprise: The Belt and Road policy. }\end{array}$ & EU SME Centre & (Daniel \& Ryan, 2018) \\
\hline $\begin{array}{l}\text { Analysis founded on the ground of initiative: China and } \\
\text { South Asia business Competition and Complementary: }\end{array}$ & Chinese Studies & $(\mathrm{Si}, 2017)$ \\
\hline $\begin{array}{l}\text { National Scientific Research on Collaboration between } \\
\text { China and Belt and Road-Based on the Frontier Gravity } \\
\text { method. }\end{array}$ & $\begin{array}{l}\text { American Journal of Industrial and Business } \\
\text { Management }\end{array}$ & (Huan, 2019) \\
\hline $\begin{array}{l}\text { China's combined onwards action in the Xi Jinping era - } \\
\text { institutional improvements and performances. }\end{array}$ & Journal of Contemporary East Asia Studies & (Suzuki, 2019) \\
\hline $\begin{array}{l}\text { Local finances in the age of Belt and Road with } \\
\text { opponent-Globalization. }\end{array}$ & Modern Economy & (Lai, Tang, \& Yin, 2018) \\
\hline $\begin{array}{l}\text { An Endemica Reply to China's Maritime Silk Road } \\
\text { Initiative in Southeast Asia. }\end{array}$ & Journal of Contemporary China & (Shaofeng, 2017) \\
\hline The Chinese high jump external: Belt and Road. & China Analysis & (Relations, 2015) \\
\hline $\begin{array}{l}\text { Rendering Strategy of Culture-gravity Words in outreach } \\
\text { ingredients under the ground of the Belt and Road. }\end{array}$ & Creative Education & (Fei, 2019) \\
\hline $\begin{array}{l}\text { A modern context in the place: One Belt and One Road } \\
\text { Initiative of China. }\end{array}$ & Bangladesh Journal of Tariff and Trade & (Islam \&Askari, 2015) \\
\hline $\begin{array}{l}\text { Agreement on the Global business hassle adjustment with } \\
\text { China One Belt and One Road Initiative. }\end{array}$ & Beijing Law Review & $(\mathrm{Hu}, 2019)$ \\
\hline China's Initiative an Objections and Advantages. & German Development Institute & (Wolff, 2016) \\
\hline $\begin{array}{l}\text { Analysis of the Belt and Road hinterland: Between India } \\
\text { and China business Competition and Complementary. }\end{array}$ & Modern Economy & (Li K. , 2018) \\
\hline $\begin{array}{l}\text { Influences of the Carat Canal on the evolution of hub ports } \\
\text { under China's initiative. } \\
\text { Impacts of Organizational Friction on Chinese Endeavor } \\
\text { Investment under the nations in Belt and Road policy. }\end{array}$ & $\begin{array}{l}\text { Transportation Research Part E: Logistics } \\
\text { and Transportation Review } \\
\text { Modern Economy }\end{array}$ & $\begin{array}{l}\text { (Zeng, Qu, Wang, \& Li, } \\
\text { 2018) } \\
\text { (Yue, 2017) }\end{array}$ \\
\hline One belt one road one Bank & Standard Chartered Bank (China) Limited & (Bank S. C., 2017) \\
\hline $\begin{array}{l}\text { China's advantages and Challenges: Collaboration } \\
\text { China-Africa under the policy. }\end{array}$ & Chinese Studies & (Zhou B. , 2019) \\
\hline $\begin{array}{l}\text { The Security Problems of the Belt Road Initiative and } \\
\text { China's Choices. }\end{array}$ & Croatian International Relations Review & (Haiquan, 2017) \\
\hline
\end{tabular}

Majority researches have been done by scholars on these initiatives but many of them are on the strategy publications of initiatives. Only some publications have been done on the grounding of the policy, prospects, objections for implementation, and synthesis for development in the future globally.

\section{Results and Discussion}

\subsection{China's Economic Strategy: Formulations, Motivations, Funding Aid, and Geographical Covering}

\subsubsection{Formulations}

China had connected in the former three decades, the enacting-up policy as followed on sustainable infrastructural extension, rise International trade relations and exporting accessible commodities. China turns economic gradually in current times and the policy intents to enhance the China's economy by manufacturing a big mart in the world especially in central Asia (Weifeng \& Mario, 2018). Across by the increase of labor charge, commodities are shorter conflict and factory movement slowly to complete in the bordering states. For China its difficult to handle this alteration from a fundamental model of enhancement to modern policy for solid finance improvement, meanwhile,China has the foresight to the big origin of foreign direct investment. Figure 2 mentions the map of belt and road initiative major areas. In this part of raising an objection condition, China realizes for the conversion of the finance development model which recommends the renaissance coordination which is now informed as economic strategy. 


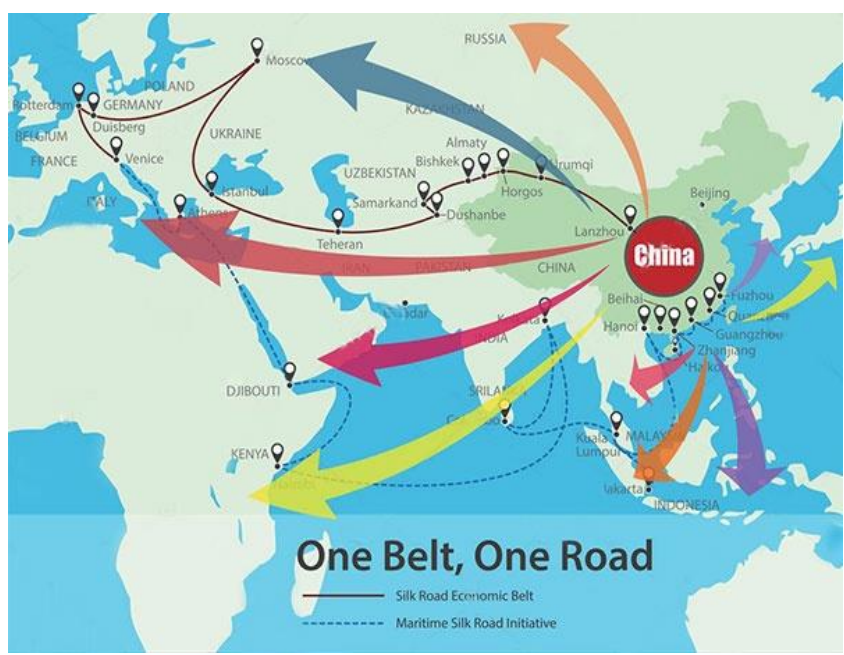

Figure 1. Map focusing areas under one belt one road initiative

\subsection{Motivations}

The concentrations of the Belt and Road initiative are to involve the community worldwide in a period of diplomatic propagation, economic extension, and cultural exchange. The primary aims of Belt and Road initiative are attaining strategy cooperation into fellows, creating an infrastructure for developing a connection, enhancing business, inspiring economic integration and developing kinship among the people of neighbor's countries (Huang, 2016). Strategy cooperation more craves consistency between partners especially open trade contracts in items of custom, endorsement and investigation administration. Person to person relations wants social activity and interaction between the peoples of all the nations toward the Silk Road malignancy the cultural inequality under them.

The policy has been a concentration on absence links in subsisting ways of transportation, elevated attribute railways, port simplify, airways and seaway, the pipeline of oil and fuel and telecommunication for improving connectivity among partner countries (Shao, Jun, Sheu, \& Gao, 2018).

To be earmarked, China wants to increase the territory's infrastructure and put in the area a safe and proficient link of ground, ocean, and air ascension, rescuing their involvement to a superior target; to major promote Business and investment supporting, introduce connectivity of duty-free business places that call superb, sustain familiar financial bonds, and profound diplomatic belief; to raise cultural activities; to motivate various courtesy to prepare from each other and magnificence at one time; and to enhance reciprocal responding, tranquility and alliance within people of all countries.

\subsection{Funding Aid}

The huge amount of capital money will essential for improving investment and infrastructural plans for increasing connectivity with Belt and Road partners. Infrastructure improvement straightly mentions on railways, highways, seaports, and airways. The Asian Infrastructure Investment Bank declared in 2014 particularly sacrificed for trading the economical affair of One belt One road.

Table 1. The funding source of Chinese economic strategy

\begin{tabular}{lccc}
\hline \multicolumn{1}{c}{ Institutions } & Loan (Yearly) & $\begin{array}{c}\text { Approved Amount } \\
\text { (US\$ billion) }\end{array}$ & \begin{tabular}{c} 
Loan yearly possibility express by 2020 \\
\hline Silk Road Found
\end{tabular} \\
$\begin{array}{l}\text { New Development Bank } \\
\text { Multilateral Development Banks }\end{array}$ & $2-3$ & 40 & $2-3$ \\
Asian Infrastructure Investment Bank & $1-1.5$ & 100 & $5-7$ \\
Policy Banks & Calculated the US \$90 billion yearly lendings by the 'Large four' banks in 2016 \\
Commercial Banks & & 1.7 & 100 \\
China Development Bank & - & $24(2015)$ & - \\
Export-Import Bank of China & - & & - \\
\hline
\end{tabular}

Source: Oxford Economics annual reports and press releases (2017). 
Table 2 mentioned about one belt one road is a massive and historical bilateral strategy so it the essential amount of funding support. The Silk Road fund has announced $\$ 40$ billion to help the government to implement the belt and road initiative. In 2015, several financing organizations such as China Export-Import Bank, China Investment Corporation, China Development Bank and the State Administration of Foreign Exchange have declared allotment funds. Infrastructure development targets immediately on roads, rail lines, airports, and seaports. The resources will be used by shareholders to improve the industry and infrastructural projects to develop engagement between One belt one road. in 2014, the Asian Infrastructure Investment Bank was Launched specifically devoted to managing financial affairs at One belt one road and has been received a preliminary capital of $\$ 100$ billion particularly for making construction and infrastructure development. China's financial Institutions commended to give investment for over nine hundred mega projects that include charcoal and fuel, electricity, infrastructure, Telecommunications, digging, and farming in almost sixty countries. This will help minimize the vacuum between demand and supply to expend on infrastructure improvement.

\subsection{Geographical Covering}

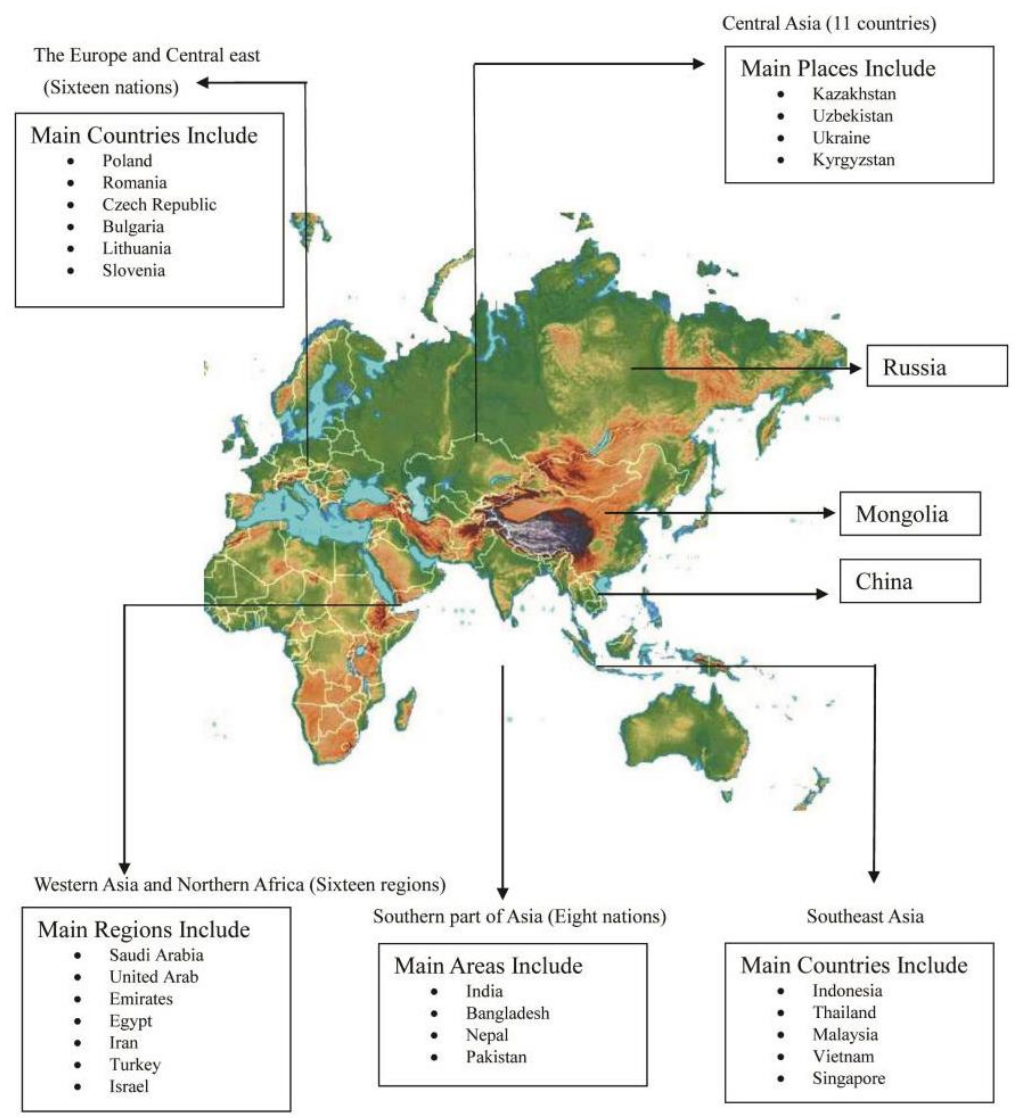

Figure 2. Map shows countries that are effectively engaged by the Belt and Road

Source: PwC analysis (www.pwc.com/).

The purpose of Belt and Road policy is to connectivity the global from China to Europe and Africa forward its couple of large program through road, air and ocean pathways. The geographical place that is dynamically included by the Belt and Road initiative is grandiose. In its present features, the initiative has covered to Sixty five countries linked to more than half of the world's people; about 30 percent of the international finance with full infrastructural investment must have about US\$5 trillion (China's new Silk Road, 2016).

Belt and Road are not to be noticed as friendship and it pressures the truth that the initiative enters accept any diplomatic rope connected. Since this perhaps so, it is pure to trust that Chinese aid and currency will come through its private fit of situations, which do cover more interest grants, a necessity to usage Chinese labor, commodities and technology and a way to payment lengthy entrance to usual funds.

\subsection{Implications for the Future of International Projects}

The glance of global economic initiatives to bring about profitable financial enhancement by integrating with 
various important development initiatives, not to browbeaten other countries. Although China has many economic advantages that it wants to assess extensively, its pockets are not profound enough to manage the large investments needed to make a sustainable policy. It expects contribution along various shareholders, associations and investment savings, effectively opening chances for various shared plans and Government-private friendship initiatives. It is a potential way for ongoing economic improvement from Asia to Africa and Europe by infrastructure development and enhancing economic streams between all co-partners nations. China has succeeded in establishing a ground link from Southeast China to Southeast Asia, which was the target of the Asian Development Bank and others for building road connectivity. Comparatively Central Asia's economy is much less than Chinese current economy. Because of the this global economic model, In future China highest supplier of products in Middle Asia, as well as the high purchaser of agro products alongside Central Asia sources (Alfred, 2014). Figure 4 demonstrates comprehensively benefits attained by the first surge of Belt and Road, particularly for trades that hub on infrastructure creating, inclusive collectors of machinery, elements include ingredients, raw components with several material to China's building associations.

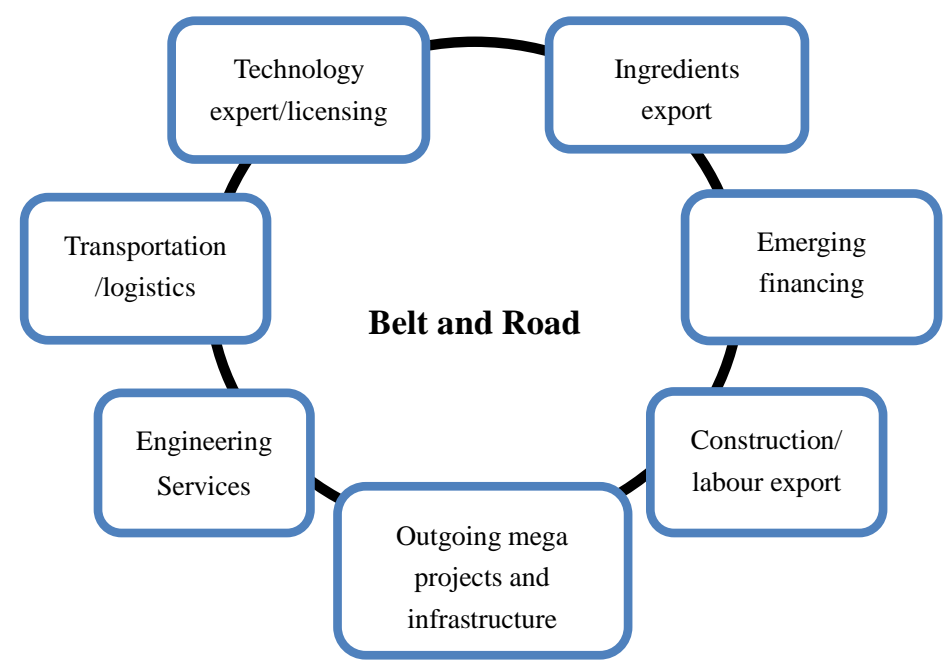

Figure 3. Some of the key opportunities arising from the Belt and Road policy

Source: Secondary research, PwC analysis (www.pwc.com/).

Moreover, there are advantages for overseas communities that have formerly confirmed smaller fruitful in staving into the Chinese market. Besides, region-owned strategy confirms in China will lid especial projects during any diplomatic or communal case. Somewhat geopolitical areas would be financially sustainable after the exact implementation of Belt and Road policy.

\subsection{Objections Connected to the Implementation of an Initiative}

Safety objections are principal challenges for co-partner nations, which is hard to handle the indigenous and exotic typical security of the shareholders' regions (Haiquan, 2017). In a few events, it probably affected by the Chinese solder. Geopolitical challenges also main objections for implementing the strategy. The affinity among India and Pakistan is defective and not assistance to administrative policy. As the between China and Pakistan corridor surpass Pakistan Controlled Kashmir which is the ultimate contrary to the Indian government. Various shareholder nations undergo diplomatic fluidity and embargo, corruption, forfeiting and uselessness that sentiment the conquest of the Belt and Road policy (Djankov \& Miner, 2016).

Geographically and topographically most of the countries different. It is not easy to build a transport pathway joining large topography to small topography areas. Big distances, increase and decrease topographic, frequent woodland places, and mountains might be thought when designing and making the lands.

Infrastructure is insufficient to get the right financial advantages from international policy (Qiangwu, 2015). The infrastructure of shareholder areas should be regarded when improving the infrastructure for the appropriateness of the initiative. As China is present forwarding financial downturn, ongoing financing for infrastructure perhaps moves objections and influences from regional administrations to improve economical and worse liability (He, 2016). So, it is significant to evoke various effective economical fellow to develop the condition.

In addition to financing from the Chinese government and the Asian Infrastructure Investment Bank, particular 
saving acquires an essential for infrastructure.

\section{Conclusion and Recommendation}

The article analyzes compatibility of Belt and Road for the posterior of Universal improvement in periods of financial durability, diplomatically viability and strengthen bonding people to people, and shows that the initiative has a large dynamic for the oncoming of inclusive improvement. It also analyzes the context of the source, prospect, policy, objection, and extension of initiative about its suitability to the whole improvement.

Furthermore; discussed China has a big impact on the initiative as an opener and inspiring Chinese forward-West strategy but overall it has a high impression on the financial part with shareholder such a globally. This study explores a few large exceptions, such as Ultimate shape and range, great infrastructure improvement, several geographic and topographic exceptions and safety relationship among the areas. It recommended potential cooperation within the co-partners is essential to achieve the full consequences of One Belt One Road by assistance act, perfect policy implementation of appropriate strategies, bright attainment process, and earnest discretion on diplomatic, economic and global causes. This research cooperates with the incoming argument on the appropriate and antithetical impacts of initiative through pursuing the Principal, policies, objections, advantages, and contexts involved in growing a global future.

\section{Acknowledgments}

We would like to extend our gratitude to Nazeer Ahmed, James Maowolo and Abukari Alhassan for appropriate statistical annex and provided remarkable assistance in gathering the article were also from. We appreciate the comments and suggestions by Richard John Tiika and Shantwana for the whole manuscript.

\section{References}

Alfred, J. A. (2014). The Silk Road in World History: A Review Essay. Asian Review of World Histories, 105-127. https://doi.org/10.12773/arwh.2014.2.1.105

Aqeel, M. (2016). Impact of China Pakistan Economic Corridor. In M. Aqeel (Ed.), Impact of China Pakistan Economic Corridor. ARCADA.

Bank, S. C. (2017). One Bank One road one Bank. Standard Chartered Bank (China) Limited.

Boamah, J., Appiah-Kubi, M., \& Osei, M. (2018, August). Network Structure Analysis of Bilateral Investments of One Belt, One Road Initiative countries. Scholars Bulletin, 689-699.

Centre, P. G. (2016). China's new silk route The long and winding road. Retrieved from http://www.pwc.com/gmc

Chaisse, J., \& Matsushita, M. (2018). China's 'Belt And Road' Initiative: Mapping the World Trade Normative and Strategic Implications. Journal of World Trade, 163-186.

Chen, Z. V., \& P, S. K. (2014). China's regulatory framework for outward foreign direct investment. China Economic Journal, 141-163. https://doi.org/10.1080/17538963.2013.874072

Chua, A. C. (July 6, 2017). One Belt One Road and Opportunities. Guangzhou, China: Center for Financial Stability.

Daniel, G. O., \& Ryan, M. (2018). The Belt and Road Initiatives: Opportunities and Challenges for EU SMEs. EU SME Centre.

Djankov, S., \& Miner, S. (2016). China's Belt and Road Initiative Motives, Scope, and Challenges. Peterson Institute for International Economics. PIIE Briefing, 16(2), 1-35. Retrieved from https://www.piie.com/system/files/documents/piieb16-2_1.pdf

Du, M. M. (2016). China's “One Belt, One Road” Initiative: Context, Focus, Institutions, and Implications. The Chinese Journal of Global Governance, 30-43. https://doi.org/10.1163/23525207-12340014

Duan, F., Ji, Q., Liu, B. Y., \& Fan, Y. (2018). Energy investment risk assessment for nations along China's Belt \& Road Initiative. Journal of Cleaner Production, 535-547. https://doi.org/10.1016/j.jclepro.2017.09.152

F. Blanchard, J. M., \& Flint, C. (2017). The Geopolitics of China's Maritime Silk Road initiative. Geopolitics, 223-245. https://doi.org/10.1080/14650045.2017.1291503

Fang, T. (2016). Relationship between Logistics and Economic Growth on the Silk Road Economic Belt. Technology and Investment, 135-142. https://doi.org/10.4236/ti.2016.74015

Fei, L. (2019). Translation Strategies of Culture-Loaded Words in Publicity Materials under the Background of 
"the Belt and Road". Creative Education, 839-847. https://doi.org/10.4236/ce.2019.105062

Ferdinand, P. (2016). Westward ho-the China dream and 'one belt, one road': Chinese foreign policy under Xi Jinping. Oxford ox4 2dq, UK: John Wiley \& Sons Ltd. https://doi.org/10.1111/1468-2346.12660

Haiquan, L. (2017). The Security Challenges of the "One Belt, One Road" Initiative and China's Choices. Croatian International Relations Review, 129-147. https://doi.org/10.1515/cirr-2017-0010

He, H. (2016). Key Challenges and Countermeasures with Railway Accessibility along the Silk Road. Engineering, 288-291. https://doi.org/10.1016/J.ENG.2016.03.017

He, M., Zequn, H., \& Ningning, Z. (2016). An Empirical Research on Agricultural Trade between China and "The Belt and Road" Countries: Competitiveness and Complementarity. Modern Economy, 1671-1686. https://doi.org/10.4236/me.2016.714147

He, T. (2017, 06 13). One Belt, One Road: How Will Partners Profit? Retrieved from http://www.brinknews.com/one-belt-one-road-how-will-partners-profit/?utm_source=BRINK+Asia

Hsueh, C. (2016). Taiwan's Perspective on China's "One Belt, One Road" Strategy. Journal of Contemporary East Asia Studies, 37-60. https://doi.org/10.1080/24761028.2016.11869096

Hu, R. (2019). Treaties on the International Trade Dispute Settlement and the China "Belt and Road" Initiative. Beijing Law Review, 441-454. https://doi.org/10.4236/blr.2019.103026

Huan, W. (2019). Research on National Scientific Research Cooperation between China and the "One Belt and One Road"-Based on the Frontier Gravity Model. American Journal of Industrial and Business Management, 1234-1253. https://doi.org/10.4236/ajibm.2019.95083

Huang, Y. (2016). Understanding China's Belt \& Road Initiative: Motivation, framework and assessment. China Economic Review, 314-321. https://doi.org/10.1016/j.chieco.2016.07.007

Islam, N. I., \& Askari, M. M. U. R. (2015). Belt and Road Initiative of China: A New Hope in the Region. Bangladesh Journal of Tariff and Trade, 18-25.

Jinghan, Z. (2017). Does Europe Matter? The Role of Europe in Chinese Narratives of 'One Belt One Road' and 'New Type of Great Power Relations. Journal of Common Market Studies, 1-15. https://doi.org/10.1111/jcms.12535

Kaplan, Y. (2017). China's OBOR as a Geo-Functional Institutionalist Project. Baltic Journal of European Studies, 7-23. https://doi.org/10.1515/bjes-2017-0002

Karl, P. S., \& Chen, V. Z. (2014). China's regulatory framework for outward foreign direct investment. China Economics Journal, 141-163. https://doi.org/10.1080/17538963.2013.874072

Kevin, G., \& Craig, N. M. (2013). Introduction: rising powers and the future of global governance. Third World Quaterly, 183-193. https://doi.org/10.1080/01436597.2013.775778

Konings, J. (2018). Trade impacts of the Belt and Road Initiative. Amsterdam: Economic \& Financial Analysis.

Lai, L. T., Tang, J., \& Yin, H. (2018). Spatial Economics in the Era of One Belt One Road and Counter-Globalization. Modern Economy, 61-66. https://doi.org/10.4236/me.2018.91004

Li, j., Xiao, F. C., Wei, W. Q., Lei, X., You, D. L., \& Rui, S. J. (2017). Renewable and sustainable energy of Xinjiang and development strategy of node areas in the "Silk Road Economic Belt". Renewable and Sustainable Energy Reviews, 274-285. https://doi.org/10.1016/j.rser.2017.05.031

Li, K. (2018). China and India Trade Competition and Complementary: Analysis of the "Belt and Road" Background. Modern Economy, 1213-1227. https://doi.org/10.4236/me.2018.97079

Liang, W. (2015). New Ideas of the Reform in the View of Globalization: Shanghai Pilot Free Trade Zone and One Belt and One Road. Open Journal of Social Sciences, 149-155. https://doi.org/10.4236/jss.2015.312016

Mishra, R. (2016). Asian Infrastructure Investment Bank: An Assessment. India quaterly A Journal of International Affairs, 163-176. https://doi.org/10.1177/0974928416643582

Peter, W. (2016). China's "Belt and Road" Initiative-Challenges and Opportunities. German Development Institute, Bonn.

Qiangwu, Z. (2015). China's New International Development Initiative-Asian Infrastructure Investment Bank:Opportunities and Challenges. Beijing: Asia-Pacific Finance and Development Center, MOF China. 
Qian, X. (2016). The New Silk Road in West Asia under "the Belt and Road" Initiative. Journal of Middle Eastern and Islamic Studies (in Asia), 26-55. https://doi.org/10.1080/19370679.2016.12023277

Relations, E. C. (2015). "One Belt, One Road": China's Great Leap Outward. China Analysis.

Research, C. F. (2019, 5 27). Belt and Road Initiative to Boost World Gdp by Over $\$ 7$ Trillion Per Annum by 2040. Retrieved from https://cebr.com/reports/belt-and-road-initiative-to-boost-world-gdp-by-over-7-trillion-per-annum-by-2040/

Sarker, M. N., Hossin, M. A., Yin, X., \& Sarkar, M. K. (2018). One Belt One Road Initiative of China: Implication for Future of Global Development. Modern Economy, 623-638. https://doi.org/10.4236/me.2018.94040

Sevilla Jr, H. A. (2017). China's New Silk Route Initiative: Political and Economic Implications for the Middle East and Southeast Asia. Asian Journal of Middle Eastern and Islamic Studies, 83-106. https://doi.org/10.1080/25765949.2017.12023327

Shao, Z. Z., Jun, M. Z., Sheu, B. J., \& Gao, H. O. (2018). Evaluation of large-scale transnational high-speed railway construction priority in the belt and road region. Transportation Research Part E: Logistics and Transportation Review, 40-57. https://doi.org/10.1016/j.tre.2017.07.007

Shaofeng, C. (2017). Regional Responses to China's Maritime Silk Road Initiative in Southeast Asia. Journal of Contemporary China, 344-361. https://doi.org/10.1080/10670564.2018.1410960

$\mathrm{Si}$, X. (2017). China and South Asia Trade Competition and Complementary: Analysis Based on the Background of "One Belt and One Road". Chinese Studies, 108-122. https://doi.org/10.4236/chnstd.2017.62010

Sidaway, J. D., \& Yuan, W. C. (2017). Chinese Narratives on “One Belt, One Road” (一带一路) in Geopolitical and Imperial Contexts. The Professional Geographer, 591-603. https://doi.org/10.1080/00330124.2017.1288576

Suzuki, T. (2019). China's United Front Work in the Xi Jinping era - institutional developments and activities. Journal of Contemporary East Asia Studies, 83-98. https://doi.org/10.1080/24761028.2019.1627714

Uberoi, P. (2016). Problems and Prospects of the BCIM Economic Corridor. China Report, 19-44. https://doi.org/10.1177/0009445515613868

Wang, X., Li, Y., \& Hu, J. (2018). Analysis on the Agricultural Trade between China and Countries along "One Belt, One Road". Modern Economy, 1977-1986. https://doi.org/10.4236/me.2018.912123

Weifeng, Z., \& Mario, E. (2018). Beyond Balancing: China's approach towards the Belt and Road Initiative. Journal of Contemporary China, 487-501. https://doi.org/10.1080/10670564.2018.1433476

Wolff, P. (2016). China's 'Belt and Road' Initiative - Challenges and Opportunities. German Development Institute.

Yang, B. (2017). China's Low-Carbon Economy Development and Carbon Finance Market Supervision Mechanism. Low Carbon Economy, 97-105. https://doi.org/10.4236/lce.2017.84008

Yu, S., \& Sun, S. (2019). Belt and Road Initiative in China: The Impact of Real Openness on Service Trade. American Journal of Industrial and Business Management, 1431-1445. https://doi.org/10.4236/ajibm.2019.96094

Yue, G. (2017). Influences of Institutional Differences on Chinese Enterprises' Investment on Countries in "The Belt and Road" Strategy. Modern Economy, 551-566. https://doi.org/10.4236/me.2017.84042

Zeng, Q., Qu, C., Wang, G. W., \& Li, X. K. (2018). Impact of the Carat Canal on the evolution of hub ports under China's Belt and Road initiative. Transportation Research Part E: Logistics and Transportation Review, 96-107. https://doi.org/10.1016/j.tre.2017.05.009

Zhou, B. (2019). Cooperation between China and Africa under the One Belt One Road Initiative: China's Benefits and Problems. Chinese Studies, 27-41. https://doi.org/10.4236/chnstd.2019.82003

\section{Copyrights}

Copyright for this article is retained by the author(s), with first publication rights granted to the journal.

This is an open-access article distributed under the terms and conditions of the Creative Commons Attribution license (http://creativecommons.org/licenses/by/4.0/). 